\title{
Effect of the energy level of the diet of Holstein cows in early and mid-lactation on the sanitary and hygienic quality of milk
}

\section{Efecto del nivel energético de la dieta de vacas Holstein en lactancia temprana y media sobre la calidad higiénica y sanitaria de la leche}

\author{
Juan Esteban Gómez-Martínez ; Albeiro López-Herrera²; José Julián Echeverri-Zuluaga ${ }^{3}$
}

\begin{abstract}
'Zoot, M.Sc. Universidad Nacional de Colombia, Research Group on Biodiversity and Molecular Genetics - BIOGEM. Medellín - Antioquia, Colombia; e-mail: juegomezma@unal.edu.co; (D) https://orcid.org/0000-0002-7904-6057

'Zoot, MV, M.Sc., Ph.D. Universidad Nacional de Colombia, Research Group on Biodiversity and Molecular Genetics - BIOGEM. Medellín - Antioquia, Colombia; e-mail: alherrera@unal.edu.co; (D) https://orcid.org/0000-0003-1444-3470
\end{abstract}

${ }^{3}$ Zoot, M.Sc., Ph.D. Universidad Nacional de Colombia, Research Group on Biodiversity and Molecular Genetics - BIOGEM. Medellín - Antioquia, Colombia; e-mail: jjecheve@unal.edu.co; (D) https://orcid.org/0000-0002-9613-0621

How to cite: Gómez-Martínez, J.E.; López-Herrera, A.; Echeverri-Zuluaga, J.J. 2021. Effect of the energy level of the diet of Holstein cows in early and mid-lactation on the sanitary and hygienic quality of milk. Rev. U.D.C.A Act. \& Div. Cient. 24(1):e1677. http://doi. org/10.31910/rudca.v24.n1.2021.1677

Open access article published by Revista U.D.C.A Actualidad \& Divulgación Científica, under Creative Commons License CC BY-NC 4.0

Official publication of the Universidad de Ciencias Aplicadas y Ambientales U.D.C.A, University, Accredited as a High-Quality Institution by the Colombian Ministry of Education.

Received: August 13, 2020 Accepted: April 16, $2021 \quad$ Edited by: Helber Adrian Arévalo Maldonado

\begin{abstract}
During the first weeks of lactation, the energy balance of dairy cows is generally negative, allowing for decompensation in a variety of tissues and systems, especially the immune system. The energy levels of a cow's diet during the first third of lactation, in specialized dairying, will modulate the immune system functionality of the mammary glands. The aim of this study was to assess the sanitary quality of milk through the somatic cell score (SCS), the colonyforming units (CFU), and the isolated bacteria of Holstein cows with different energy levels in the diet. Thus, 24 Holstein cows were studied during their first third of lactation, after the lactation peak (50 to 100 lactation days). They were assigned into 4 treatments, taking into account the energy requirements of each animal: Isoenergetic (ISO), Hypoenergetic (HYPO), Hyper energetic (HYPER), and
\end{abstract}

Isoenergetic plus sunflower oil supplementation (OIL). Milk samples were taken for the somatic cell count (SCC) and CFUs, and isolated pathogens in milk were identified by microbiological culture. The diet had a significant effect on SCS with a value $\mathrm{p}$ of 0.0331 , but not on the CFUs $(\mathrm{p}<0.5141) .11$ pathogens were identified and in $33.9 \%$ of samples, microorganisms were not isolated. The Isoenergetic diet favors the presence of some microorganisms and the increase of SCS.

Keywords: Antibiotics; Diet energy; Mastitis; Microorganisms; Milk.

\section{RESUMEN}

En las primeras semanas de lactancia, generalmente, el balance energético de la vaca lechera es negativo, determinando una 
descompensación en diferentes tejidos y sistemas, en especial, el inmunológico. Los niveles de energía en la dieta de vacas, en primer tercio de lactancia en lechería especializada, modularán la funcionalidad del sistema inmune en glándula mamaria. El objetivo del presente trabajo fue evaluar la calidad sanitaria de la leche, a través de la medición de células somáticas (SCS), las unidades formadoras de colonias (UFC) y las bacterias aisladas de vacas Holstein, con diferentes niveles de energía en la dieta. Se usaron 24 vacas Holstein en el primer tercio de gestación, posterior al pico de lactancia (entre 50 y 100 días de lactancia), dispuestas en 4 tratamientos, de acuerdo con el cubrimiento de los requerimientos energéticos del animal: isoenergético (ISO), hipoenergético (HIPO), hiperenergetico (HIPER) e isoenergético más suplementación con aceite de girasol (ACEITE). Se tomaron muestras de leche para el recuento de células somáticas (RCS) y UFC y se identificaron patógenos en leche, por cultivos microbiológicos. La dieta tuvo un efecto significativo sobre el SCS, con un valor p de 0.0331 y no sobre las UFC $(\mathrm{p}<0.5141)$. Se identificaron 11 patógenos y en $33,96 \%$ de las muestras no se aislaron microorganismos. La dieta isoenergética favorece la presencia de algunos microorganismos y el aumento del SCS.

Palabras clave: Antibióticos; Energía dietaria; Mastitis; Microorganismo; Leche.

\section{INTRODUCTION}

In dairy cows, the transition period between the three weeks before parturition and the three weeks after it is characterized by dramatic modifications, especially in physiological, endocrinological, and nutritional aspects (Castro-Ruiz et al. 2017). At the beginning of the lactation, there is an energetic deficiency (Álvarez et al. 2006), since there is a sudden increase of the energy requirements because of the high demand for galactopoietic, which increases the mobilization of body reserves to keep the milk yield (Esposito et al. 2014).

There is evidence that energy restriction alters most of the immunologic mechanisms, including a delayed response in the production of antibodies, reduced proliferative capacity of lymphocytes and the interleukin activity, and reduced phagocytic capacity and viability of neutrophils (Tizard, 2009).

Mastitis is an inflammatory reaction of the mammary gland that causes physical and chemical alterations in the milk, increases the somatic cell count due to pathogens, and finally, produces loss of functionality of this tissue (Villa-Arcila et al. 2017). The mammary gland is at special high risk of infection in dairy herds (Reyes, 2015) during negative energy balance periods, because this tissue contains all the necessary components to sustain life, being thus highly attractive to invading microorganisms seeking to exploit such resources to their benefit (Tizard, 2009). These microorganisms could be frequently found in the animal itself or the surrounding environment (including the milkers). So, while microorganisms such as Staphylococcus aureus, Streptococcus agalactiae, Corynebacterium bovis, and Mycoplasma spp. can cause contagious mastitis, others like Escherichia coli, Klebsiella spp., Enterobacter spp., Serratia spp., Pseudomonas spp. and Proteus spp., and some gram-positive bacteria like Streptococcus uberis and Streptococcus dysgalactiae can produce environmental mastitis (Calderón \& Rodríguez, 2008).

Immune components of bovine mammary glands act as a defense against pathogens, including innate and specific immunity (Sordillo \& Streicher, 2002) and the proper functioning of these defense systems will rely, greatly, on the degree of infection and the mammary gland's physiological stage (Meglia \& Mata, 2001) which can be measured through SCS. Furthermore, both the quantity and type of microorganisms found in milk is a kind of information reflecting sanitary conditions, at several levels, during milk yield in dairy farms, such aspects can be measured with the CFUs (Kunová et al. 2017). Nonetheless, it has a limited diagnostic value concerning the specific identification of the contaminant bacterium (Ruiz-Cortés et al. 2012), which could be solved through the identification of microorganisms in microbiological cultures.

There are also other mechanisms, apart from the biological, to control mammary gland infections, where antibiotics therapy plays a major role. Nevertheless, a significant disadvantage of this therapy is that, besides being used in the treatment of intramammary infections, it is also administered as a prophylactic to prevent diseases during the cow's dry period, between one lactation and the next, favoring thus the selection of resistant strains and the generation of residue in the dairy product (Pellegrino et al. 2011).

Nutrition is a key element in the proper functioning and development of the immune system during an animal's lifespan (Zapatera et al. 2015). The supplementation with fatty acids is sometimes used to increase both dietary energy and milk yield (He \& Armentano, 2011) and, naturally, to favor the animal's immune system and to strengthen the milk's fatty acids profile.

The aim of this work was to evaluate if different levels of energy in the diet of Holstein cows in the first third of lactation modulate the functionality of the immune system in the mammary gland, reflected through the SCC, CFUs, and the identification of pathogens in milk.

\section{MATERIALS AND METHODS}

This research project was endorsed by the Universidad Nacional de Colombia ethics committee (CEMED 037), 2014.

Target population. 24 Holstein cows multiparous (2 to 6 parturition), during the second half of the first third of lactation (50 to 100 lactation days) were studied. They were selected to form a group as homogeneous as possible in live weight between 500 and $600 \mathrm{~kg}$, and milk yield $41 \pm 7.6 \mathrm{~L}$ on average. The cows do not have health problems either mammary gland alterations. The study was carried out at the Paysandú farming station at the Universidad Nacional de Colombia, Medellín (Santa Elena village), during the second semester of the year.

Treatments with different energy levels and sources in the diet. All 24 cows were assigned into 4 treatments, 6 cows each. 
The diet was based on kikuyu grass Pennisetum clandestinum Hochst. ex Chiov. and a type of balanced feed ration considering the raw material described in table 1 and made at the San Pablo concentrated food processing farming station at the Universidad Nacional de Colombia.

The treatments assessed were treatment 1 (control) Isoenergetic diet (ISO) fulfilling 100\% of cow's energy requirements, treatment 2 Hyper energetic diet (HYPER) 115\%, 15\% over the cow's energy requirements, treatment 3 Hypoenergetic diet (HYPO) fulfilled up to $85 \%$ of the cow's energy requirements and treatment 4 , isoenergetic diet plus sunflower oil supplementation (OIL), 6\% over the cow's energy requirements.

Animals were fed adding concentrated food to the estimated forage intake to reach $100 \%$ of the energy requirements. Besides, the concentrated food was added with $350 \mathrm{~g}$ of sunflower oil to be administered during each of the two milkings, corresponding to $6 \%$ of additional energy requirements.

A pilot test was carried out aimed at estimating individual intake of kikuyu grass, using chromium oxide as an external marker and indigestible dry matter (DM) as an internal marker, following the described methodologies by Lippke (2002) and Mojica et al. (2009).

The calculation of Net energy of lactation (NEl) was carried out from Gross energy (GE) and Total Digestible Nutrients (TDN) using the NRC-2001 formulas for both the forage and the balanced feed. Then, an evaluation of the NEl requirements was made for each of the cows under study using the NRC-2001 formulas, using the milk quality and yield milk daily of each one. From this energy, requirements were subtracted those contributed by the energy supplied from the forage according to the previous study, and the amount of missing energy (depending on the treatment the cow was in) was supplied increasing or decreasing the amounts of balanced feed distributed in the morning and afternoon milking.

Milk samples. The animals had 25 treatment days, where samples were taken the days $0,5,10,15,20,23,24$ and 25. Milk samples were taken in the morning milking and the afternoon and they were sent in refrigeration at $4^{\circ} \mathrm{C}$, before two hours, to the Milk Safety and Quality Laboratory of the University of Antioquia for the measure of CFUS (in preservative Azidiol®) and SCC (in Bronopol ${ }^{\circledR}$ preservative) counting. And for the microbiological culture samples were taken to the diagnostic unit of the veterinary microbiology laboratory.

Statistical analysis. A logarithmic transformation of the somatic cell count data was performed to be converted to somatic cell score (SCS) to obtain normality, according to the expression Log2 (SCC / 100000) +3, as described by Dabdoub \& Shook (1984) and for the CFUs analysis, a logarithmic transformation was performed, according to the expression Log (CFU) as described by ÁlvarezFuentes et al. (2012). Following this, a normality test was carried out for both variables and when this assumption was met, a repeated measures test was carried out for each one, using the proc mixed

Table 1. Raw material for the elaboration of balanced feed and bromatological analysis of balanced food and grass Pennisetum clandestinum.

\begin{tabular}{|c|c|c|c|c|}
\hline \multicolumn{2}{|c|}{ RAW MATERIAL OF THE BALANCED FEED } & \multicolumn{3}{|c|}{ BROMATOLOGICAL ANALYSIS } \\
\hline Ingredients & Inclusion $(\%)$ & Analysis & Balanced Feed (\%) & Grass (\%) \\
\hline CORN & 56.4 & $\mathrm{CP}^{\mathrm{a}}$ & 16.5 & 23.5 \\
\hline MANDIOC & 10 & NDIP $^{b}$ & 0.7 & 11 \\
\hline WHEAT BRAN & 7.21 & $\mathrm{ADIP}^{\mathrm{c}}$ & 0.8 & 2.4 \\
\hline PALM OIL & 2 & $\mathrm{NDF}^{\mathrm{d}}$ & 10.9 & 61.9 \\
\hline SOY FLOUR & 18 & $\mathrm{EE}^{\mathrm{e}}$ & 5.01 & 3.1 \\
\hline CANE MOLASSES & 4 & Ash & 6.2 & 10.2 \\
\hline CALCITE (CACO3) & 0.62 & Lignin & 2.1 & 4.6 \\
\hline MONO-DICALCIUM PHOSPHATE & 0.99 & NSC $^{f}$ & 62.09 & 12.3 \\
\hline SODIUM CHLORIDE (MARINE) & 0.3 & NDF:NSC ${ }^{g}$ & 0.18 & 5.03 \\
\hline VITAMIN PREMIXING. & 0.25 & NEl(Mcal) ${ }^{h}$ & 1.9 & 1.1 \\
\hline MINERAL PREMIXING. & 0.25 & & & \\
\hline
\end{tabular}

${ }^{\mathrm{a}}$ Crude protein; ${ }^{\mathrm{b}}$ Neutral detergent insoluble protein; ${ }^{\mathrm{c}}$ Acid detergent insoluble protein; ${ }^{\mathrm{d}}$ Neutral detergent fibre; ${ }^{\mathrm{e}}$ Ethereal extract; ${ }^{\mathrm{f}}$ Non-structural carbohydrates; ${ }^{\mathrm{g}}$ Relationship between NDF and NSC; ${ }^{\mathrm{h}}$ Net energy of lactation (in mega-calories). 
command from SAS $®$ software version 9.2 (SAS Institute Inc., 2009). The models used to describe the SCS and CFUs variables were the next, respectively:

$(\mathrm{SCS}) \mathrm{Y}_{\mathrm{ijklmnopqrs}}=\mu+\mathrm{D}_{\mathrm{i}}+\mathrm{CN}_{\mathrm{j}}+\mathrm{DIM}_{\mathrm{k}}+\mathrm{TD}_{\mathrm{l}}+\left(\mathrm{YP}_{\mathrm{m}} * \mathrm{MP}_{\mathrm{n}}\right)+$

$\mathrm{MY}_{\mathrm{o}}+\mathrm{CFU}_{\mathrm{p}}+\mathrm{P}_{\mathrm{q}}+\mathrm{MT}_{\mathrm{r}}+\mathrm{C}_{\mathrm{s}}\left(\mathrm{D}_{\mathrm{i}}\right)+\varepsilon$

$(\mathrm{CFU}) \mathrm{Y}_{\mathrm{ijklmnopqrs}}=\mu+\mathrm{D}_{\mathrm{i}}+\mathrm{CN}_{\mathrm{j}}+\mathrm{DIM}_{\mathrm{k}}+\mathrm{TD}_{\mathrm{l}}+\left(\mathrm{YP}_{\mathrm{m}} * \mathrm{MP}_{\mathrm{n}}\right)+\mathrm{MY}_{\mathrm{o}}$

$+\mathrm{SCS}_{\mathrm{p}}+\mathrm{P}_{\mathrm{q}}+\mathrm{MT}_{\mathrm{r}}+\mathrm{C}_{\mathrm{s}}\left(\mathrm{D}_{\mathrm{i}}\right)+\varepsilon$

$\mathrm{Y}_{\mathrm{ijklmnopqrs}}=$ Dependent variable.

$\mu=$ Mean of the dependent variable.

$\mathrm{D}_{\mathrm{i}}=$ Fixed effect of diet $\mathrm{i}(\mathrm{i}=1,2,3$ and 4$)$.

$\mathrm{CN}_{\mathrm{j}}=$ Fixed effect of calving number $\mathrm{j}(\mathrm{j}=2,3,4,5$ and 6$)$.

$\mathrm{DIM}_{\mathrm{k}}=$ Fixed effect of days in milk k ( $\mathrm{k}=50$ to 100 days).

$\mathrm{TD}_{\mathrm{l}}=$ Fixed effect of test day $\mathrm{l}(\mathrm{l}=1,2,3,4,5,6,7$ and 8$)$.

$\mathrm{YP}_{\mathrm{m}} * \mathrm{MP}_{\mathrm{n}}=$ Interaction effect of calving year $\mathrm{m}(\mathrm{m}=1$ and 2$)$

and calving month $\mathrm{n}(\mathrm{n}=1$ to 12$)$

$\mathrm{MY}_{\mathrm{o}}=$ Fixed effect of milk yield o (o $=33 \mathrm{Kg}$ to $49 \mathrm{Kg}$ ).

$\mathrm{CFU}_{\mathrm{p}}=$ Fixed effect of CFUs $\mathrm{p}(\mathrm{p}=0$ to 2$)$.

$\mathrm{SCS}_{\mathrm{p}}=$ Fixed effect of SCS $\mathrm{p}(\mathrm{p}=1$ to 13$)$.

$\mathrm{P}_{\mathrm{q}}=$ Fixed effect of the amount of isolated pathogens $\mathrm{q}(\mathrm{q}=0$,

1, 2 and 3).

$\mathrm{MT}_{\mathrm{r}}=$ Fixed effect of the mastitis type $\mathrm{r}(\mathrm{r}=0,1,2$ and 3).

$\mathrm{C}_{\mathrm{s}}\left(\mathrm{D}_{\mathrm{i}}\right)=$ Random effect of the s-th diet nested cow.

$\varepsilon=$ Error.

Then, a correlation was made with the Proccorr command of SAS® software version 9.2 (SAS Institute Inc., 2009), between the SCSs and the transformed CFUs. A histogram was made with each of the identified microorganisms and with all the cows under study (Figure 1). Two microorganisms' categorizations were carried out according to their relationship with either contagious or environmental mastitis, to the number of pathogens isolated per sample for the diet's association with the type of pathogen isolated, and to the number of pathogens isolated per sample. This analysis was based on a 95\% confidence interval and an OR (Odds Ratio) (Cerda et al. 2013).

\section{RESULTS AND DISCUSSION}

The milk production mean during the trial was 36.9L with a SE 7.8L for all treatments. The diets HYPER and OIL had the lowest mean for this variable, 34.8 and 34.9L, respectively, with a SE of 10.9 and $5 \mathrm{~L}$ in the same sense. The HYPO diet had a mean and a SE of 36.9 and $8.3 \mathrm{~L}$, respectively. Lastly, the highest production milk mean was the diet ISO, 38.8L and its SE was 5.9L. The SCS mean in general was 8 and a SE 2.1 and for the treatments, HYPO, ISO, HYPER, and OIL was $8.9 \pm 2.3,6.7 \pm 1.7,7.9 \pm 2.4$ and $7.5 \pm 1.9$, respectively, for the general trial time. For the CFUT variable, the general mean during the trial period was 1.43 with a SE of 0.22 . The ISO diet had the lowest mean for the variable above, $1.17 \pm 0.24$, and the highest mean was the diet HYPO with 1.9 \pm 0.22 . The CFUT means for the diets HYPER and OIL, were $1.32 \pm 0.4$ and $1.66 \pm 0.2$, respectively, according to the general trial.

In the model was observed that the diet had a significant effect on the SCS, with a p-value of 0.03 , this parameter being the only significant parameter within the chosen model (Table 2).

The diet with the lowest mean for SCS was the Isoenergetic diet and, in contrast, the diet with the highest mean for this same parameter was the Hypoenergetic diet.

Table 2. Minimum mean-square for each diet and difference of minimum mean-squares between diets for SCS and CFUT variables.

\begin{tabular}{|c|c|c|c|c|c|c|}
\hline \multirow{2}{*}{ DIET } & \multicolumn{3}{|c|}{ SCS } & \multicolumn{3}{|c|}{ CFUT } \\
\hline & EM & \multicolumn{2}{|c|}{$\mathrm{SE}$} & EM & \multicolumn{2}{|c|}{ SE } \\
\hline HYPOENERGETIC & 7.3301 & \multicolumn{2}{|c|}{0.7879} & 1.6029 & \multicolumn{2}{|c|}{0.2177} \\
\hline ISOENERGETIC & 4.1813 & \multicolumn{2}{|c|}{0.7624} & 1.1520 & \multicolumn{2}{|c|}{0.2356} \\
\hline HYPERENERGETIC & 6.7280 & \multicolumn{2}{|c|}{1.1845} & 1.2514 & \multicolumn{2}{|c|}{0.3257} \\
\hline OIL & 6.3354 & \multicolumn{2}{|c|}{1.0006} & 1.5680 & \multicolumn{2}{|c|}{0.2750} \\
\hline CONTRAST & ED & $\mathrm{SE}$ & $\operatorname{Pr}>t$ & ED & SE & $\operatorname{Pr}>t$ \\
\hline HYPO vs ISO & 3.1487 & 0.9899 & $0.0087 *$ & 0.4509 & 0.3158 & 0.1811 \\
\hline HYPO VS HYPER & 0.6021 & 1.3215 & 0.6575 & 0.3515 & 0.3573 & 0.3464 \\
\hline HYPO VS OIL & 0.9947 & 1.2679 & 0.4493 & 0.03494 & 0.3361 & 0.9191 \\
\hline ISO VS HYPER & -2.5466 & 1.1299 & $0.0456 *$ & -0.09942 & 0.3227 & 0.7637 \\
\hline ISO VS OIL & -2.1540 & 1.3027 & 0.1264 & -0.4160 & 0.3580 & 0.2698 \\
\hline HYPER VS OIL & 0.3926 & 1.4699 & 0.7943 & -0.3165 & 0.3818 & 0.4247 \\
\hline
\end{tabular}

* Statistically significant difference between the means; EM = Estimated mean; SE = Standard error; ED = Estimated difference; Pr $>$ $\mathrm{t}=\mathrm{p}$ - value. 


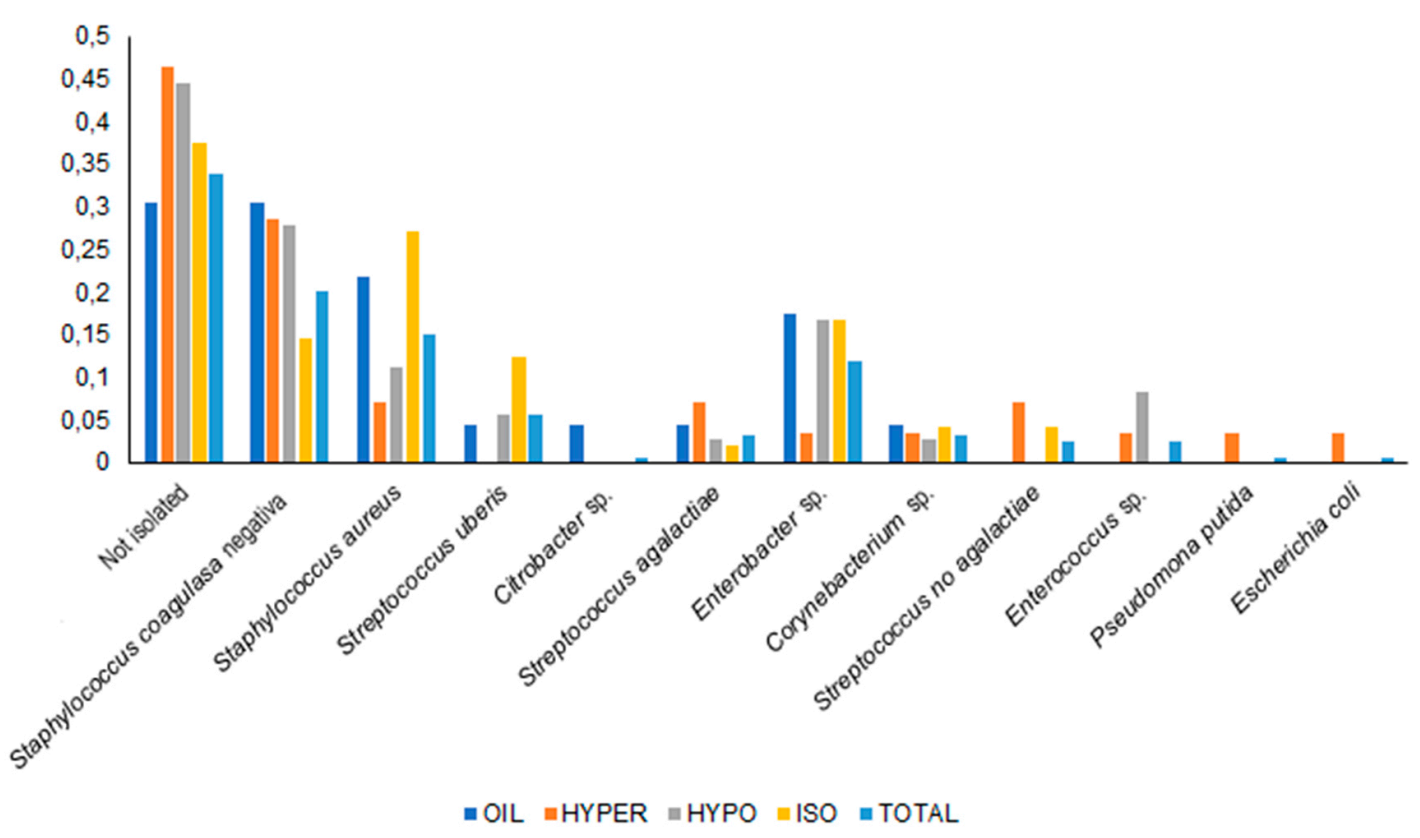

Figure 1. Frequency of eleven microorganisms isolated of milk of 24 multiparous cows in early and mid-lactation, in four treatments with different coverage of the required energy level and the general or total frequency for each isolation in the study.

Regarding the differences between minimum mean-squares, there was a significant difference between the means of the HYPO and the ISO diets, as well as a significant difference between the means of the ISO and the HYPER diets. The difference between means was not significant between the ISO and OIL diets, nor was the contrast significant between means of the HYPO, HYPER, and OIL diets, or the OIL and HYPER diets (Table 2).

The HYPO diet that obtained a higher SCS had an average higher than the one reported by Pinedo \& Melendez (2010) in Chile since this was 4.77. However, the standardization used in the abovementioned article enabled the low value for the SCS, since that value represents, for the article, 308,000 somatic cells per milliliter, which in this study would represent a score of 8.08.

No report on the effect of the energy level of the diet on the SCS count was found, which makes this study a pioneer in this kind of analysis. However, it was observed that there was indeed a significant effect of such parameter on the response variable, as reported by Tizard (2009), who states that the greatest influence on the health of the cow's mammary gland is the feeding (energy intake); therefore, deficiencies in the energy and protein contributions weaken the functioning of the immune system (increasing the SCC) and enabling pathogens invasion (increasing the CFUs).

The increase of the SCS in cows with food alterations is due to the fact that the small number of somatic cells, which are usually found in the mammary gland and belong to the innate immune system, are not able to resolve intramammary infections that are increasingly recurrent and require, therefore, a greater number of immune cells and the acquired immune system, bringing significant changes in the somatic cell count (Sordillo \& Streicher, 2002).
In this model, no parameter had a significant effect on the CFUs response variable, including the diet that showed a $\mathrm{p}$-value of 0.5141 .

The estimated mean with the lowest value for the CFUs with logarithmic transformation was the ISO control diet, while, on the contrary, the HYPO diet obtained the highest average; the same was true for SCS. Therefore, there was no statistically significant difference between the various contrasts between the means of all the diets (Table 2).

The CFUs mean of this study was 149,000CFUs/mL, lower than the established within the hygienic quality standards proposed by Resolution 017 (MADR 2012), which is between 175,000 and $200,000 \mathrm{CFUs} / \mathrm{ml}$. The lowest mean of CFUs found in this study was observed in the ISO diet with an adjusted value of 1.1520, which represents a value of $25,000 \mathrm{CFUs} / \mathrm{ml}$, well below that reported by Vásquez et al. (2012), since in that study for Medellín the mean was $122,000 \mathrm{CFUs} / \mathrm{ml}$. However, in this study, the diet with the highest CFUs average was the HYPO diet with a value of 256,000CFUs/ $\mathrm{ml}$, which is even much higher than that of Barranquilla, the region with the highest CFUs average in Colombia (Vásquez et al. 2012).

There were no statistical differences between the means of the variable of the different treatments, which can be understood from the factors that affect the variable that is largely environmental and, therefore, external to the animal, as mentioned by Ruiz-Cortés et al. (2012), where the CFUs are mostly affected by the type of milking (manual or mechanical), the region's altitude, and the time in the milk churn or the temperature at which milk is kept.

Also, the milk's hygienic quality is affected by microbiological factors influenced, in turn, by the practice of cleaning, disinfection, and 
environmental hygiene at the time of milking (Hurtado-Lugo et al. 2005), so, possibly, the diet did not have a significant effect on the CFUs, since there are other factors that may alter this parameter to a greater extent, although it should be clarified that, in this study, the animals of the different treatments were subject to the same hygienic and sanitary practices.

The correlation obtained between the somatic cell score (SCS) and the colony-forming units with the logarithmic transformation (CFUT) was moderate to the low correlation of $35.6 \%$ with a p-value of 0.0001 .

The SCC in milk can also be altered by CFUs, especially by some microorganisms-bacteria that are classified as contagious and environmental (Colorado et al. 2018), so a relationship between SCC and CFUs is to be expected. The correlation found in this work of $35.6 \%$ was higher than that reported by Cerón-Muñoz et al. (2016) which was $11 \%$. In this sense, the moderate-high correlation observed in this work could be mainly due to two factors. The first factor is the logarithmic transformations made both to the SCC and to the CFUs, where the distant values may have more proximity after the transformation; and the second factor is that the minimum mean-squares for both SCC, represented in SCS, and for CFUs, represented in CFUT, keep a similar order from lowest to highest, where the lowest values apply for the ISO treatment and the highest for the HYPO.

In Colombia, the averages for SCC and CFUs in specialized dairying are 400,000-600,000cells/mL and 395,551CFUs/mL, respectively (Carulla \& Ortega, 2016), which are averages higher than those found in this work, especially in the ISO treatment, in which the SCC was 22,852 cells $/ \mathrm{ml}$, and the CFUs was 25,000 per $\mathrm{mL}$. The higher values of SCS are undesirable because they represent a health problem for the mammary gland (Colorado et al. 2018), and the high values of CFUs, due to represent a lower bacteriological quality of the milk (Vásquez et al. 2012).

Regarding the microbiological analysis, the observed value for the frequency of non-isolations, of $33.9 \%$, was higher than that described by Ramírez et al. (2011), which was $23.9 \%$. It was also higher than the reported by Gasque \& Blanco (2001) and Colorado $e t$ al. (2018), which for both was $29.86 \%$. The explanation of the high prevalence of negative samples, or without isolation, is understood from a biological point of view, where bacteria are intermittently eliminated by the functioning of the immune system, according to Gasque \& Blanco (2001). This could happen in the HYPO diet since it showed a high SCS, or as in the case of the ISO diet, where the pathogen displayed in low amount since this treatment had the lowest mean for CFUs.

Samples that did not show isolates were also included in this study (Figure 1). It was possible to identify 11 different microorganisms. The samples that did not show the isolation of microorganisms obtained the highest frequency in all the diets with a general frequency of 33.96\%, followed by the coagulase-negative Staphylococcus microorganism, which obtained the highest frequency in most treatments except for the ISO treatment, where the Staphylococcus aureus showed the highest frequency. Both with general frequencies of $20.13 \%$ and $15.09 \%$, respectively. The microorganism associated with environmental mastitis that appeared with greater frequency was Enterobacter spp. with a frequency of $11.95 \%$, whereas Escherichia coli, as well as Pseudomona putida, only appeared in the treatment HYPER.

The predominant microorganism in the study was coagulasenegative Staphylococcus with isolation in all samples in 33.96\% -a bacterium classified as responsible for contagious mastitis, unlike the reported by Villa-Arcila et al. (2017), where such microorganism was the second most frequent, after the Staphylococcus aureus. Colorado et al. (2018) reported that Arcanobacterium haemolyticum was found to be the most frequently isolated pathogen in the specialized milking systems of northern Antioquia, with a presence in $20.84 \%$ of the total samples evaluated, being this value much higher than that found in this study for this microorganism, which was only $3.14 \%$ of the total of the isolated samples, while in the study by Colorado $\mathrm{et} \mathrm{al}$. (2018) the presence of coagulase-negative Staphylococcus was lower than that found here, since it had a value of $18.4 \%$.

On the other hand, S. uberis had a total isolation frequency of 5.66\%, like that reported by Villa-Arcila et al. (2017), which fluctuated between $11.4 \%$ from the dry period of the cows to $5.4 \%$ in the fourth week postpartum. Similar results were also reported by Calderón \& Rodríguez (2008), with a 5.7\% frequency. Streptococcus agalactiae had a lower frequency in this study, $3 \%$ than that reported by Colorado et al. (2018), which was $13.8 \%$. This pathogen has been, for a long time, the most known causative agent of mastitis, and can cause severe septicemia and meningitis in neonates (Wolter et al. 2004) and its lowest percentage of isolation was shown in the ISO diet with $2 \%$.

As for the pathogens E. coli, Pseudomona putida and Citrobacter spp., that can generate serious clinical mastitis (Klaas \& Zadoks, 2017) as they are environmental agents, and their presence in this study was due, probably, to cross-contamination by the manipulation of the sample by the milkers. These agents showed up in $0.63 \%$ of the cases, which translates into a case for each of them, which is like the findings by Villa-Arcila et al. (2017).

Of the eleven microorganisms identified, five are related to contagious mastitis and six to environmental mastitis; but some of these microorganisms may present strains with both kinds, for instance, Leelahapongsathon et al. (2020) observed through molecular analysis that Streptococcus uberis can have contagious strains and environmental strains with spontaneous cure. The OR between the ISO control diet and the other diets and the presence or absence of microorganisms related to contagious mastitis or environmental mastitis were determined (Table 3). This allowed to determine that the ISO diet had a protective effect in comparison with the other diets regarding the presence of microorganisms associated with contagious mastitis, with a $95 \%$ confidence interval. No protective or risk effect of the ISO diet was found in comparison with the other diets regarding the presence of microorganisms associated 
with environmental mastitis. No effect was observed either regarding the number of isolated microorganisms with a confidence interval of $95 \%$ (Table 3).

No studies were found related to the ORs which associate the diet's energy intake and the type of isolated microorganism (contagious or environmental), as was the case here. Despite this fact, results are encouraging, since in the case of contagious pathogens, the ISO diet with a $0.77 \mathrm{OR}$, seems to have a protective effect, which suggests that the use of antibiotics for the control of causative pathogens of subclinical contagious mastitis can be diminished if the animal's energy requirements are considered and that higher or lower intakes may favor the environmental pathogens contamination of the bovine mammary gland, since, as mentioned by Wolter et al. (2004), the improvements in the milking processes and hygiene must be accompanied by improvements in the feeding and management of the herd and the facilities. In this sense, the good functioning of the immune system linked to good nutritional conditions can keep the contagious microorganisms in balance, especially those in the skin of the mammary gland (Tizard, 2009).

In conclusion, the level of energy in the diet modulates the SCS but no the CFUs in Holstein dairy cows in the first third of lactation. Particularly the isoenergetic diet has the best benefits about those variables, and this diet could help to protect the dairy cows of pathogens related to contagious mastitis.

Acknowledgments. This work has been funded by the project "Modulating gene expression in the mammary glands of Holstein cows via nutritional factors", Contract 2015-021, Colciencias.

Table 3. Associations of the ISO diet with the type of microorganism isolated and the number of microorganisms isolated.

\begin{tabular}{|c|c|c|}
\hline ASSOCIATIONS & OR & CONFIDENCE INTERVAL at $\mathbf{9 5 \%}$ \\
\hline CONTAGIOUS MASTITIS & 0.777 & $0.185-0.857$ \\
\hline ENVIRONMENTAL MASTITIS & 0.454 & $0.457-2.290$ \\
\hline NUMBER OF PATHOGENS & 1.666 & $0.854-3.911$ \\
\hline
\end{tabular}

Conflict of interests: The authors declare no conflict of interests, or any economic, personal, or political relation affiliation, nor any financial or academic interest that may influence their judgment during this study.

\section{REFERENCES}

1. ÁlVAREZ-FUENTES, G., HERrERA-HARO, J.G.; ALONSO-BASTIDA, G.; BARRERAS-SERRANO, Y A. 2012. Calidad de la leche cruda en unidades de producción familiar del sur de Ciudad de México. Arch. Med. Vet. 44:237-242.

http:/ /dx.doi.org/10.4067/S0301-732X2012000300005

2. ÁlVAREZ, H.J.; BICHIO, L.; PESCE, M.A.; CANGIANO, C.A.; GALLI, J.R. 2006. Producción de leche bovina con distintos niveles de asignación de pastura y suplementación energética. IJANR (Chile). 33(2):99-107.

3. CALDERÓN, A.; RODRÍGUEZ, V.C. 2008. Prevalencia de mastitis bovina y su etiología infecciosa en sistemas especializados en producción de leche en el altiplano cundiboyacense (Colombia). Rev Colomb Cienc Pecu. 21(4):582-589.

4. CARULLA, J.E.; ORTEGA, E. 2016. Sistemas de Producción Lechera En Colombia: Retos y Oportunidades. Arch. latinoam. prod. anim. 24(2):83-87.
5. CASTRO-RUIZ, S.M.; GALVIS-GÓEZ, R.D.; LÓPEZHERRERA, A.; GIRALDO-GIRALDO, J.J. 2017. Efecto Del Nivel de Suplementación Con Propilenglicol Durante El Período de Transición a La Lactancia Sobre Actividad Ovárica Y Desempeño Reproductivo En Vacas Holstein. Revista Lasallista de Investigación (Colombia). 14(2):30-40. https://doi.org/10.22507/rli.v14n2a3.

6. CERDA, J.; VERA, C.; RADA, G. 2013. Odds ratio: Theoretical and practical issues. Rev. méd. Chile. 141(10):1329-1335 http://dx.doi.org/10.4067/S0034-98872013001000014

7. CERÓN-MUÑOZ, M.F.; CHAVES-GALEANO, F.P.; PALACIO, L.G. 2016. Paradigma de la valoración de pago de la leche cruda: calidad composicional, higiénica y sanitaria en Colombia. Livest. Res. Rural. Dev. (Colombia). 28:202.

8. COLORADO, J.J.; ECHEVERRY-ZULUAGA, J.J.; OLIVERA-ANGEL, M.; LÓPEZ-HERRERA, A. 2018. Microorganismos aislados en cultivo bacteriológico de muestras de leche de vacas Holstein clínicamente sanas. Rev. CES Med. Zootec (Colombia).13(1):31-41. http://dx.doi.org/10.21615/cesmvz.13.1.3

9. DABDOUB, S.M.; SHOOK, G.E. 1984. Phenotypic relations among milk yield, somatic cell count and clinical mastitis. J Dairy Sci (U.S.A). 67:163-164. https://doi.org/10.3168/jds.s0022-0302(05)72747-8 
10. ESPOSITO, G.; PETE, C.I.; EDWARD, C.W.; ASPINAS, C. 2014. Interactions between Negative Energy Balance, Metabolic Diseases, Uterine Health and Immune Response in Transition Dairy Cows. Animal Reproduction Science (Netherland). 144(3-4):60-97. http://dx.doi.org/10.1016/j.anireprosci.2013.11.007

11. GASQUE, R.; BLANCO, M. 2001. Zootecnia en bovinos productores de leche, $1^{\text {st }}$ edition, FMVZ-UNAM, Mexico. p.246.

12. HE, M.; ARMENTANO, L.E. 2011. Effect of fatty acid profile in vegetable oils and antioxidant supplementation on dairy cattle performance and milk fat depression. J Dairy Sci (U.S.A). 94(5):2481-2491.

https://doi.org/10.3168/jds.2010-3755

13. HURTADO-LUGO, N.; CERÓN-MUÑOZ, M.; TONHATI, H.; GUTIERREZ-VALENCIA, A.; HENAO, A. 2005. Producción de la leche en búfalas de la Costa Atlántica colombiana. Livestock Research For Rural Development (Colombia). 17(12).

14. KLAAS, I.C.;ZADOKS, R.N. 2017. An update on environmental mastitis: Challenging perceptions. Transbound Emerg Dis (United Kingdom). 65(1):166-185. https://doi.org/10.1111/tbed.12704

15. KUNOVÁ, S.; GOLIAN, J.; ZELEŇÁKOVÁ, L.; LOPAŠOVSKÝ, L.; ČUBOŇ, J.; HAŠČÍK, P.; KAČÁNIOVÁ, M. 2017. Microbiological quality of fresh and heat treated cow's milk during storage. Potr. S. J. F. Sci. 11(1):652-657. https://doi.org/10.5219/799

16. LEELAHAPONGSATHON, K.; SCHUKKEN, Y.H.; SRITHANASUWAN, A.; SURIYASATHAPORN, W. 2020. Molecular epidemiology of Streptococcus uberis intramammary infections: Persistent and transient patterns of infection in a dairy herd. J. Dairy Sci. 103(4):3565-3576. https://doi.org/10.3168/jds.2019-17281

17. LIPPKE, H. 2002. Estimation of forage intake by ruminants on pasture. CROP SCI. (U.S.A). 42(3):869-872. https://doi.org/10.2135/cropsci2002.0869

18. MEGLIA, G.; MATA, H. 2001. Mecanismos específicos e inespecíficos de defensa, con referencia a la glándula mamaria de los bovinos productores de leche. Ciencia Veterinaria (Argentina). 3(1):29-40.

19. MINISTERIO DE AGRICULTURA Y DESARROLLO RURAL-MADR. 2012. Resolución número 017 de 2012 "Por el cual se establece el sistema de pago de la Leche Cruda al Proveedor". 18p.
20. MOJICA, J.E.; CASTRO, E.; LEÓN, J.; CÁRDENAS, E.A.; PABÓN, M.L.; CARULLA, J.E. 2009. Efecto de la oferta de pasto kikuyo (Pennisetum clandestinum) sobre la producción y calidad composicional de la leche bovina. Livestock Research for Rural Development (Colombia). 21(1).

21. NATIONAL RESEARCH COUNCIL, NRC. 2001. Nutrient Requirements of Dairy Cattle. 7th rev. ed. Natl. Acad. Sci. (Washington, DC.). 65-67.

22. PELlEGRINO, M.S.; FROLA, I.D.; ODIERNO, L.M.; BOGNI, C.I. 2011. mastitis bovina: resistencia a antibióticos de cepas de Staphylococcus aureus aisladas de leche. REDVET (Argentina). 12(7):1-14

23. PINEDO, P.; MELENDEZ, P. 2010. Patrones temporales de recuento de células somáticas, grasa, proteína y nitrógeno ureico en leche de estanque y su asociación con fertilidad en ganado lechero en la zona centro-sur de Chile. Arch. med. vet. (Chile). 42(1):41-48. http://dx.doi.org/10.4067/S0301-732X2010000100006

24. RAMÍREZ, V.; ARROYAVE, H.; CERÓN-MUÑOZ, M.; JARAMILLO, M.; CERÓN, J.; PALACIO, G. 2011. Factores asociados a mastitis en vacas de la microcuenca lechera del altiplano norte de Antioquia, Colombia. Rev. Med. Vet. (Colombia). 22:31-42.

25. REYES, M.P. 2015. Principales vulnerabilidades en la mastitis bovina en una empresa pecuaria oriental de cuba (main vulnerabilities in bovine mastitis in eastern cattlecompany of Cuba). REDVET (Argentina). 16(5):1-9.

26. RUIZ-CORTÉS, T.; OROZCO, S.; RODRÍGUEZ, L.S.; IDÁRRAGA, J.; OLIVERA, M. 2012. Factores que afectan el recuento de UFC en la leche en tanque en hatos lecheros del norte de Antioquia-Colombia. Rev. U.D.C.A. Act. \& Div. Cient. (Colombia). 15(1):147-155. https://doi.org/10.31910/rudca.v15.n1.2012.812

27. SAS INSTITUTE INC. 2009. SAS/STAT 9.2 User's Guide cary, NC, USA. Second edition. Available from Internet in: http://support.sas.com/documentation/cdl/en/ statugmcmc/63125/PDF/default/statugmcmc.pdf

28. SORDILLO, L.M.; STREICHER, K.L. 2002. Mammary gland immunity and mastitis susceptibility. J Mammary Gland Biol Neoplasia (U.S.A). 7(2):135-146. https://doi.org/10.1023/A:1020347818725

29. TIZARD, I.R. 2009. Introducción a la inmunología veterinaria. Elsevier, $8^{\text {th }}$ edition. Texas (U.S.A). p.591.

30. VÁSQUEZ, J.F.; LOAIZA, E.T.; OLIVERA, M. 2012. Calidad higiénica y sanitaria de leche cruda acopiada 
en diferentes regiones colombianas. ORINOQUIA (Colombia).16(2):13-23.

31. VILLA-ARCILA, N.A.; DUQUE-MADRID, P.C.; LASSOROJAS, L.; SÁNCHEZ-ARIAS, S.; CEBALLOSMÁRQUEZ, A. 2017. Etiología de las infecciones intramamarias subclinicas al secado y en el postparto en vacas lecheras en Caldas, Colombia. Revista Científica (Venezuela). 27(4):227-334.
32. WOLTER, W.; CASTAÑEDA, H.; KÑOPPERT, B. 2004. La mastitis bovina. prevención, diagnóstico y tratamiento. Editorial Universitaria. México. p.146.

33. ZAPATERA, B.; PRADOS, A.; GÓMEZ-MARTÍNEZ, S.; ASCENSIÓN, M. 2015. Inmunonutrición: metodología y aplicaciones. Rev Esp Nutr Comunitaria (Spain). 21(1):144153.

http://doi.org/10.14642/RENC.2015.21.sup1.5061 